\title{
Development of Learning Media for Listening Skills of German Language Based on Web DaF (Deutsch als Fremdsprache) for Students High School in Makassar
}

\author{
Laelah Azizah', Wahyu Kurniati Asri², Misnah Mannahali³ \\ 1,2,3 Foreign Language Education, Universitas Negeri Makassar, Makassar, Indonesia
}

1Email: laelahs@yahoo.com

Submitted: 05/01/2020

Revised: 17/01/2020

Accepted: 20/02/2020

E-ISSN : $2579-4574$

P-ISSN : 2549-7359

\begin{abstract}
This research aims to know the validity, practicality, and effectiveness of the DAF web-based media learning listening skills for high school students in Makassar City. The design of instructional media uses the Thiagarajan four D (4-D) model of development stages the which consists of four items, namely define, design, develop and develop. Data collection is done through validation of learning tools, observation, student questionnaire responses. The products produced in this study were lesson plans, teaching materials, and LKPD web-based learning daf listening skills. Based on the results of the analysis of the data it was concluded that the learning media for listening to the German language based on web DAF is valid, practical, and effective.
\end{abstract}

Keywords: Learning Media, DaF, German Listening Skills

\section{https://ojs.unm.ac.id/eralingua}

This work is licensed under a Creative Commons Attribution-NonCommercial 4.0 International License 


\section{INTRODUCTION}

In the current era of globalization, foreign languages, including the German language occupies a strategic position in the improvement of human resources. Lots of information science in the fields of engineering, pure sciences, economics, psychology and arts, and culture comes from the German-language books. German as a foreign language that is recognized in Indonesia, has taught in formal and nonformal at the level of secondary school (high school) and college since 1975. The outlines of the teaching program German language subjects in SMA provides guidance that subjects the German language is a foreign language subject that can serve as a student self-development tool and a tool to broaden horizons in various fields. Thus, the teaching of the German language can support the growth and development of students into citizens who are intelligent, skilled and personable Indonesia, in order to play an active role in national development (Ministry of Education, 2006: 5).

Furthermore, through the study of German language learners can develop skills in oral and written communication to understand and convey information, thoughts, and feelings. German language learning curriculum that is used today is known as the $\mathrm{K} 13$ curriculum that emphasizes the aspects of a child's character development. Curriculum 2013 more demanding creativity of teachers to stimulate the intelligence of his students. Teachers should make students more active. Teachers are not only noted and explained, but it should make comfortable schools. Applications Curriculum 2013, emphasizes the cultivation of character and culture to students educated from an early age.

Government Regulation No.19 of 2005 on National Education Standards, requires each school to develop the curriculum based on competency standards and content standards and guided by the guidelines established by the National Education Standards Agency. Each school is expected to prepare and develop the syllabus independently according to the characteristics of subjects, conditions, and needs of each school.

Azizah (2011) concluded that German language teaching materials at high school in the city of Makassar have been implemented by teachers based curriculum which runs through the German language MGMPs Makassar. The material is implemented is the syllabus and teaching materials developed from the textbooks and Kontakte Deutsch ist Einfach Deutsch. But not all the authority contained in the curriculum is fully implemented by the teachers and the school, which has not been able to develop more comprehensive teaching materials and have not been able to optimize the learning environment in schools respectively. Problems experienced in learning German certainly vary both in terms of learner motivation, learning outcomes, textbooks, learning facilities and several other problems (Qudus, M., \& Yusri, Y, 2017; Syahputra, A. F., \& Mantasiah, R., 2017; Angreany, F., \& Saud, S., 2017; Mantasiah, R., et al, 2019; Azizah, L., et al, 2018)

Based on observations at several schools in the city of Makassar, German language teachers to teach the material in accordance with the teaching materials are sourced from German textbooks Kontakte Deutsch (KD) and Deutsch ist Einfach. In the German language textbooks in high school, KD has imprinted web 
site addresses of the material that needs to be developed, but teachers generally have not done so. This has become an obstacle to the subject matter of the German language becomes less varied. Thus required the development of more innovative subject matter by taking material from various sources. Standardized teaching materials such as German language teaching materials DAF of them from the internet. The material accessible from the internet, among others obtained from the web site German language teaching for foreigners or Deutsch als FremdSprache (DAF). DAF This material is prepared for foreign learners.

Development of an integrated German language teaching implications on integrative teaching material needs as well. Teaching materials are not developed in isolation, but as a whole / intact. Hard in Jufri (2002) suggested that the units are not presented in a different language to make it more easily understood. Learning the language will be easier if it is presented in real-time, complete, relevant, and meaningful. Jufri (2002) suggests the characteristics of language learning in an integrative manner, namely: (1) as a whole, (2) that is relevant and meaningful in everyday life, (3) the spelling and vocabulary support or taught in an integrated manner in the aspects of language skills, good receptive and productive, (4) emphasize the actualization of the use of language with clear and precise objectives, (5) giving the task of thematically (not sorted).

Listening is the process of receiving sound through auditory organs in the body, while the understanding is the result of processing information received by the brain, and he understood what was delivered. So, hearing and understanding are two activities related to the so-called listening process. Listening does have an important role in the language learning process. However, listening is also a difficult skill, especially in learning a foreign language.

Rampillon (1996) argues that "Horverstehen heisst erfassen nicht nur der Laute, der grammatischen \& egmente und einer der semantischen Elemente 'außerung, aber" ververstehen heißt auch die Absichten des Sprechers) uinterpretieren ". Based on these opinions, it can be concluded that listening is considered difficult because in addition to understanding the sounds and grammatical and semantic elements of an utterance, in listening to the listener is also required to interpret the purpose intended by the speaker.

Preparation of German language learning materials has been adapted to the curriculum in 2013 Although the textbooks used in high school textbooks is simple but can be adapted and developed in accordance with the curriculum that is being run, namely issuing extra revision. Textbooks used in high school were ist Einfach Deutsch and Deutsch Kontakte (KD) that is both communicative and material are oriented in the use of language and cross-cultural interaction. The material presented thematically covers the structure and all four language skills as well as trained and developed at the same level.

DAF used material adapted to the material needs-based curriculum in 2013, which is the same material selected theme with the material to high school students in accordance with a hierarchically. Based on the National Education Standards, technical guidelines syllabus development high school for German lessons contains among others is the theme of the life of the Family: die Familie and 
themes of everyday life: Essen und Trinken, Wohnung, Kleidung, Alltagsleben (Einkauf beim Lebenmittelhandler, im Kaufhaus, im Restaurant), Wohnen, and the theme of life Schools: Der Stundenplan, Gegenstande in der Schule und Schulachen, Lehrer, Schulaktivitat.

\section{RESEARCH METHOD}

Based on the research objectives that have been formulated, this research is classified in research \& development (research and development). This development research aims to develop listening skills learning media German-based Web DAF (Deutsch als FremdSprache). The research design will be used in connection with the purpose of research, is the design of Learning Development models Thiagarajan (4D), which consists of the stages of development of learning tools. This research subject as a medium of learning trials, conducted in some senior high schools in Makassar Makassar. The school election is based on the consideration that the school has adequate internet facilities.

The data collection is done through the sheet validation study learning tools (lesson plans, teaching materials), sheet observation device implementation and learning by teachers and students' responses to the application questionnaire Webbased learning listening skills DAF. Analysis of the data obtained in the study was classified into three, namely the validity of the analysis, the analysis of the practicality and effectiveness analysis. To analyze the validity of the learning device (teaching materials and LKPD) media listening skills learning German language webbased DAF (Deutsch Als Fremdsprache), to take measures such as those used Nurdin (2007)

The validity of instructional media will be determined by comparing the value of $V_{a}$ or the average value of the total validity of the whole grains according to the validity criteria assessment Nurdin (2007) as listed in Table 1.

Table 1. Category level of validity

\begin{tabular}{cc} 
Score & Information \\
\hline $4,5 \leq M \leq 5$ & very valid \\
\hline $3,5 \leq M \leq 4,5$ & valid \\
\hline $2,5 \leq M<3.5$ & less valid \\
\hline $1,5 \leq M \leq 2,5$ & Invalid \\
\hline$M<1.5$ & Very invalid \\
\hline
\end{tabular}

Practicality media listening skills learning German language web-based DAF (Deutsch Als Fremdsprache) were analyzed with the steps that are used Nurdin (2007: 146). Practicality media measured by adherence to the use of this medium from the results of observations assessment of subject teachers and students of the German language during the process of learning takes place. Categories of implementation value learning media skills listening to German web-based DAF (Deutsch Als Fremdsprache) are presented in Table 2. 
Table 2. Category Value of implementation media listening skills learning German language web-based DAF (Deutsch Als Fremdsprache)

\begin{tabular}{cc}
\hline Interval & Kategori \\
\hline $1 \leq T K<2$ & not done \\
\hline $2 \leq T K<3$ & Less accomplished \\
\hline $3 \leq T K<4$ & quite accomplished \\
\hline $4 \leq T K<5$ & Well done \\
\hline$T K=5$ & Very successfully \\
\hline
\end{tabular}

The criteria used in determining that the media listening skills learning German language web-based DAF (Deutsch Als Fremdsprache) have a sufficient degree of enforceability is if the value of the minimum implementation quite accomplished. The effectiveness of instructional media listening skills German language web-based DAF (Deutsch Als Fremdsprache) is determined through analysis: students towards the learning media. Criteria effectiveness of teaching materials according to (Hobri, 2009), when the number of students who use the media to give positive responses greater than or equal to $75 \%(\geq 75 \%)$ of the number of subjects studied then considered effective learning media

\section{RESULT AND DISCUSSION}

Media learning listening skills German language-based Web DAF (Deutsch als FremdSprache) have been researched and developed with reference to the development model 4D made up to four steps: Define, Design, Development and Dissemination developed by Thiagarajan (1974). In the definition phase (Define) listening skills learning media products German-based Web DAF (Deutsch als FremdSprache), which also consists of curriculum analysis, analysis of learners and material analysis namely teaching and subject matter; meine Familie, die Familiestammbaum, possesivepronomen im Nominativ, das ist meine Familie, possesivepronomen im Akkusativ, Verben.

At the design stage to design a product, namely lesson plan and the components of the preparation of teaching materials and teaching materials analysis, and LKPD. RPP is prepared to take into account the application of information and communication technologies in an integrated, systematic and effective in accordance with the circumstances that generated the RPP for Horen modules that implement information technology and web-based communications. Furthermore, the instructional materials have been prepared in accordance with the curriculum and indicators achieved in the German language lessons for hören module are systematically and in accordance with the needs of students. In addition, the objectives to be achieved, the material relevant to students, and there is a barcode scan. Scan the barcode on the instructional materials allows students to access web pages related to the theme of learning. Furthermore, LKPD produced 
the LKPD in accordance with the teaching materials that have been made, namely web-based activity sheet comprising instructions, the steps to complete a task, Worksheet Students (LKPD) were adjusted according to the characteristics of students, the situation of learning activities faced, and the school environment. In addition, the resulting LKPD also includes a discussion of unit activity refers to the basic competence XI High School class of 2013 and indicators appropriate curriculum learning outcomes.

At the development stage (development) in accordance with the advice validator, that the components of the resulting product, of the component materials, must contain the title of the learning materials, basic competencies to be achieved, core competencies, learning objectives to be achieved, a barcode to access scan web DAF (Deutsch als Fremdsprache) material content web DAF, not only regarding instructional materials but also the results of the validation LKPD, validators have generally concluded that the products produced are valid and good and can be used by students, only need to be clarified regarding the aspects that well rated, the identity of the student, and the clue in Indonesian. Based on the revision indicates that the title of the material, the identity of the student, and the clue in the Indonesian language has also been met.

The tests showed that the average value of teaching materials is 4.1 , which means the category is valid. This is because the content of the teaching materials are based on the web DAF (Deutsch Als Fremdsprache) refers to the basic competence and developed properly. In addition, the developed LKPD also shows the average value is 4.17 , which means also in the category valid. Based on this, teaching materials and LKPD referring to media listening skills web-based DAF (Deutsch Als Fremdsprache) have met the design principles, namely simplicity, coherence, emphasis and continuity, which means materials and LKPD is valid for use in the process of language learning Germany, in particular the theme of die Familie. Upon validation of teaching materials and LKPD.

The results obtained from observation of implementation media listening skills learning German language web-based DAF (Deutsch Als Fremdsprache) through the assessment form from the observation of teachers and students shows that the media performing well in all three schools are the subject of the trial. From the observation of adherence to the use of Web-based media DAF (Deutsch Als Fremdsprache) SMA Negeri 11 Makassar concluded that the instructional media are included in the criteria fairly implemented or practical, with an average of 3.89, the data analysis practicality media listening skills learning German language web-based DAF (Deutsch Als Fremdsprache) from the observation of adherence to the use of Web-based media DAF SMA 3 Makassar concluded that instructional media are included in the criteria or practical performing well, with an average of 4.11 , then the observation of adherence to the use of web-based media DAF SMAN 8 Makassar concluded that instructional media are included in the criteria fairly implemented or practical, with an average of 3.03 .

The data analysis was also performed practicality from the observation of the enforceability of the students in the use of instructional media listening skills German language web-based DAF (Deutsch Als Fremdsprache). From the observation of adherence to the use of Web-based media DAF SMAN 11 Makassar 
concluded that instructional media are included in the criteria fairly implemented or practical, with an average of 3.89, the observation of enforceability use of Webbased media SMAN 3 Makassar DAF concluded that the media the study included in the criteria for performing well or practical, with an average of 4.11 , and the observation of adherence to the use of web-based media DAF SMAN 8 Makassar concluded that instructional media are included in the criteria fairly implemented or practical.

After the validity and practicality of the results obtained. Further analysis of media effectiveness listening skills learning German language web-based DAF (Deutsch Als Fremdsprache). The effectiveness of instructional media listening skills German language web-based DAF (Deutsch Als Fremdsprache) can be seen from the students' response to the use of instructional media. Student responses obtained by giving questionnaires to students after the application of listening skills German media web-based DAF (Deutsch Als Fremdsprache). Based on the analysis of the students' response to the effectiveness of instructional media listening skills German language web-based DAF (Deutsch als Fremdsprache) in the three schools that became the subject of media in Makassar trials, each of which demonstrates a positive response, ie at SMAN 11 Makassar amounted to $75.16 \%$, SMAN 3 Makassar amounted to $75.21 \%$, and SMAN 8 Makassar amounted to $76.55 \%$. Based on the criteria of effectiveness according to (Hobri, 2009), when the number of students who use the media to give positive responses greater than or equal to $75 \%(\geq 75 \%)$ of the studied subjects then said effective learning media. Of the three schools that showed that students respond greater than $75 \%$, it can be concluded that the media listening skills learning German language web-based DAF (Deutsch als Fremdsprache) is effectively used in the process of learning the German language die Familie particular theme. if the number of students who use the media to give positive responses greater than or equal to $75 \%(\geq 75 \%)$ of the studied subjects then said effective learning media. Of the three schools that showed that students respond greater than $75 \%$, it can be concluded that the media listening skills learning German language web-based DAF (Deutsch als Fremdsprache) is effectively used in the process of learning the German language die Familie particular theme. if the number of students who use the media to give positive responses greater than or equal to $75 \%(\geq 75 \%)$ of the studied subjects then said effective learning media. Of the three schools that showed that students respond greater than $75 \%$, it can be concluded that the media listening skills learning German language web-based DAF (Deutsch als Fremdsprache) is effectively used in the process of learning the German language die Familie particular theme.

Media listening skills learning German language web-based DAF (Deutsch als Fremdsprache) have valid criteria, practical, and effective. By using this media students feel happy. This media is easy to use, helping students understand the subject matter, presentation material by using instructional media listening skills German language web-based Daf made more active in learning because there is no limitation of space and time. Besides the language used is also easy to understand. In the deployment phase (Dissemination) instructional media listening skills webbased DAF (Deutsch als Fremdsprache), teaching materials, lesson plans, and LKPD generated at the final stages of development, further disseminated or distributed 
on a limited basis at the school as the place to test the media, namely SMA Negeri 11 Makassar, SMAN 8 Makassar, and SMAN 3 Makassar.

\section{CONCLUSION}

1. Development of instructional media listening skills German language web-based DAF (Deutsch als Fremdsprache) development model 4D developed by Thiagarajan (1974) which consists on 4 stages, namely Define, Design, Develop and Disseminate. Based on the results it can be concluded that: media listening skills learning German language web-based DAF (Deutsch als Fremdsprache) developed classified in the category of valid, practical, and effective.

2. The validity of instructional materials and LKPD which refers to instructional media listening skills German language web-based DAF (Deutsch als Fremdsprache) valid criteria, with expert validation result value of 4.1 for materials and 4.17 for LKPD.

3. Practicality media listening skills learning German language web-based DAF (Deutsch als Fremdsprache) is based on the observation of enforceability of the media by the teacher, has met the criteria of practical value by an average of 3.89 at SMAN 11 Makassar, the average value of 4.11 SMAN 3 Makassar and SMA 8 Makassar with an average of 3.03. Practicality is also assessed based on the observation of adherence to the use of media by students. SMAN 11 Makassar instructional media are included in the criteria fairly implemented or practical, with an average of 3.89 , SMAN 3 Makassar, with an average of 4.

4. The effectiveness of instructional media listening skills German language webbased DAF (Deutsch als Fremdsprache) relatively effective with the percentage shows that SMAN 11 Makassar amounted to $75.16 \%$, SMAN 3 Makassar amounted to $75.21 \%$, and SMAN 8 Makassar by $76,55 \%$. Based on the criteria of effectiveness according to (Hobri, 2009), when the number of students who use the media to give a positive response to a greater or equal to $75 \%(\geq 75 \%)$ of the studied subjects then said effective learning media. Of the three schools showed that students respond greater than $75 \%$, it can be concluded that the media listening skills learning German language web-based DAF (Deutsch als Fremdsprache) is effectively used in the process of learning the German language die Familie particular theme.

\section{REFERENCES}

Azizah, Laelah. (2011). Implementasi Materi Ajar Deutsch als Fremsprache (DaF) pada Pembelajaran Bahasa Jerman Siswa SMA di Kota Makassar; Disertasi, Program Pascasarjana Universitas Hasanuddin.

Azizah, L., Mannahali, M., \& Asri, W. K. (2018, November). The Effectiveness of" Sprachlabor" to Media Skills (Hörvestehen) German Language Students of German Language Education. In PROCEEDINGS OF THE 65th TEFLIN INTERNATIONAL CONFERENCE (Vol. 65, No. 02).

Departemen Pendidikan Nasional. (2006). Kurikulum 2006. KTSP, Bahasa Jerman Pilihan. Pusat Kurikulum, Balitbang Depdikbud, Jakarta.

Angreany, F., \& Saud, S. (2017). Keefektifan Media Pembelajaran Flashcard Dalam Keterampilan Menulis Karangan Sederhana Bahasa Jerman Siswa Kelas Xi Ipa 
Sma Negeri 9 Makassar. Eralingua: Jurnal Pendidikan Bahasa Asing dan Sastra, $1(2)$.

Hobri. (2009). Metode Penelitian Pengembangan (Development Research) (Aplikasi pada Penelitian Pendidikan Matematika). Jember: FKIP Universitas Jember.

Jufri. (2002). Prinsip-Prinsip Strategi Pembelajaran Bahasa. Universitas Negeri Makassar.

Mantasiah, R., Yusri, Y., Syaputra, A. F., Angreany, F., Hasmawati, H., \& Anwar, M. (2019, December). Assessing Mistake Potential in Writing German Passive Sentences (An Approach of Language Error Analysis). In Seminar Nasional LP2M UNM.

Nurdin. (2007). Model Pembelajaran Matematika yang Menumbuhkan Kemampuan Metakognitif untuk Menguasai Bahan Ajar. Disertasi. Surabaya: PPs Universitas Negeri Surabaya.

Qudus, M., \& Yusri, Y. (2017). Keefektifan Penggunaan Metode Audio Lingual dalam Pembelajaran Kemampuan Menyimak Bahasa Jerman. Indonesian Journal of Educational Studies, 20(2).

Rampillon, Ute. (1996). Forum Sprache Lerntechniken im Fremdsprachunterricht Handbuch. München: Hueber.

Syahputra, A. F., \& Mantasiah, R. (2017). Keefektifan Teknik Brainstorming Dalam Keterampilan Menulis Karangan Bahasa Jerman Siswa Kelas XI IPA. Eralingua: Jurnal Pendidikan Bahasa Asing dan Sastra, 1(2).

Thiagarajan, S., Semmel, D.S \& Semmel, M.I. (1974). Instructional Development for Training Teachers of Expectional Children, Minneapolis, Minnesota: Leadership Training Institute Special Education, University Minnesota. 